\title{
Potensi Teknologi dan Media Sosial Dalam Meningkatkan Pemasaran Produk Asuransi Syariah
}

\author{
Dita Ayu Susmita ${ }^{1}$, Nuri Aslami² \\ 1,2Fakultas Ekonomi dan Bisnis Islam, Universitas Islam Negeri Sumatera Utara \\ ditaayususmita@gmail.com ${ }^{1}$
}

\begin{abstract}
As the largest Muslim country, the country occupied by 236,53 The population is Muslim, if this is used and used as an opportunity for sharia insurance to develop rapidly in this country. Indonesia should have the potential to become the largest Muslim country where most of the Muslim population uses sharia products, especially sharia insurance. In fact, the current fact is that not many Indonesian Muslims use banking and non-banking products on the basis of sharia principles. AAJI's data report, if users of insurance products in Indonesia still reach 7.5\%, and only 5\% of them are users of sharia insurance. The lack of awareness of knowledge and the lack of strong exposure to sharia insurance products are indicators of the reason why there is still a small level of customer participation using sharia insurance. This reason is further strengthened when viewed from the literacy rate for sharia insurance in Indonesia which has only reached a nominal figure of 19,4\%. For this reason, considering the widespread use of social media in Indonesia, which is dominated by the current millennial and generation $Z$, the marketing strategy of sharia insurance is now starting to move by utilizing the digitalization of marketing media. This study is intended to find out the potential influence of technology and social media in helping to increase sales of sharia insurance products in terms of marketing aspects. Observational analysis of previous research and of sharia insurance companies that carried out this marketing strategy, obtained the findings that social media marketing and the compliance of several insurance products that apply sharia principles in it, are significantly able to increase people's purchasing power or contribute significantly. Indirectly persuade social media users to determine their decision to buy sharia insurance products.

Key words : Sharia insurance marketing, Social media, Technology.
\end{abstract}

\begin{abstract}
ABSTRAK
Sebagai negara muslim terbesar, negara yang ditempati 272,23 juta Penduduk beragama muslim, sudah seharusnya jika hal ini dijadikan dan dimanfaatkan sebagai peluang bagi asuransi syari'ah berkembang pesat di negara ini. Indonesia harusnya berpotensi menjadi negara muslim terbesar yang juga sebagian besar penduduk muslimnya menggunakan produk syari'ah khususnya asuransi syari'ah. Nyatanya, fakta yang tampak saat ini tidak banyak penduduk muslim Indonesia yang menggunakan produk perbankan maupun non perbankan atas dasar prinsip syari'ah. Laporan data AAJI, jika pengguna produk asuransi di Indonesia masih mencapai angka 7,5\%, dan baru 5\% diantaranya merupakan pengguna asuransi syari'ah. Minimnya kesadaran akan pengetahuan dan belum kuatnya paparan akan produk asuransi syari'ah menjadi indikator alasan mengapa masih sedikit tingkat partisipasi nasabah pengguna asuransi syari'ah. Alasan ini semakin dikuatkan lagi jika dilihat dari angkan literasi terhadap asuransi syari'ah di Indonesia juga baru mencapai nominal angka $19,4 \%$. Untuk itu mempertimbangkan dengan kemarakkan penggunaan media sosial di Indonesia yang didominasi oleh generasi milenial dan generasi $\mathrm{Z}$ saat ini, strategi pemasaran asuransi syari'ah kini mulai bergerak memanfaatkan digitalisasi media pemasaran. Penelitian ini dimaksudkan untuk menemukan pengaruh potensial teknologi dan media sosial dalam membantu peningkatan penjualan produk asuransi syari'ah dari segi aspek pemasarannya. Analisis observasi akan penelitian terdahulu dan akan perusahaan asuransi
\end{abstract}




\section{VISA: Journal of Visions and Ideas \\ Vol 1 No 3 (2021) 274-287 E-ISSN 2809-2058 P-ISSN 2809-2643 \\ D0I: 47467/visa.v1i3.809}

syari'ah yang melakukan strategi pemasaran ini, diperoleh hasil penemuan jika pemasaran media sosial serta kepatuhan beberapa produk asuransi yang menerapkan prinsip syariat di dalamnya, ternyata secara signifikan mampu meningkatkan daya beli masyarakat atau turut serta bersumbangsih secara tidak langsung membujuk pengguna media sosial menentukan keputusannya untuk membeli produk asuransi syari'ah.

Kata Kunci : Pemasaran asuransi syari'ah, Media sosial, Teknologi.

\section{PENDAHULUAN}

Indonesia merupakan negara berkembang di Asia Tenggara dengan dominansi kepemilikan penduduk beragama islam terbesar di dunia, dikutip dari data BPS 2021 ada sebanyak 272,23 juta penduduk Indonesia per Juni 2021 dan sebanyak 236,53 juta atau sekitar $86,88 \%$ penduduk Indonesia yang merupakan umat muslim. ${ }^{1}$ Ini berarti kita sebenarnya berpotensi menjadi negara acuan/kiblat program 4S (Islamic Food, Islamic Fashion, Islamic Fun and Entertaiment, Islamic Finance).

Termasuk tidak menutup kemungkinan untuk asuransi syari'ah yang merupakan salah satu industri non perbankan dengan tingkat pertumbuhan 7,6 triliun menjadi 11,5 triliun pada kuartal II-2021. ${ }^{2}$ Angka ini cukup mengesankan, sayangnya berbanding terbalik dengan jumlah masyarakat muslim yang ada di Indonesia. Besarnya jumlah penduduk muslim yang ada harusnya berimbang dengan besarnya pangsa pasar asuransi syari'ahnya juga. Minimnya kepedulian dan kesadaran (concern and awareness), literasi atau pengetahuan (knowledge), serta eksplikasi paparan (exposure) akan brand asuransi syari'ah menjadi 3 indikator utama yang menyebabkan sedikit atau minimnya pula seseorang berminat terhadap produk asuransi syari'ah ${ }^{3}$.

Otoritas Jasa Keuangan (OJK) mencatatkan indeks literasi asuransi di Indonesia pada tahun 2019 mencapai 19,4\% indeks ini lebih rendah dibanding

${ }^{1}$ https://databoks.katadata.co.id/datapublish/2021/09/30/sebanyak-8688-penduduk-

indonesia-

beragamaislam\#: :text=Persentase $\% 20$ Pemeluk\%20Agama\%2FKepercayaan $\% 20$ di\%20Indonesia $\%$ 20(Juni\% 202021)\&text=Berdasarkan\%20data\%20Direktorat\%20Jenderal\%20Kependudukan,86 $\% 2 \mathrm{C} 88 \% 25) \% 20$ beragama\%20Islam.

${ }^{2}$ https://money.kompas.com/read/2021/09/21/130524326/industri-asuransi-syariahlanjutkan-pertumbuhan-positif-pada-kuartal-ii-2021

${ }^{3}$ Husin, M.dan Rahman, A. (2014). Do Muslims intend to participate in Islamic insurance? Analysis from theory of planned behaviour. Emerald Insight. 


\section{VISA: Journal of Visions and Ideas \\ Vol 1 No 3 (2021) 274-287 E-ISSN 2809-2058 P-ISSN 2809-2643 D0I: 47467/visa.v1i3.809}

indeks literasi perbankan ditahun yang sama yang telah mencapai angka 36,12\%.4 Data hasil pengindeksan pengetahuan akann literatur produk non perbankan asuransi syari'ah tersebut menunjukkan bahwasannya level kesadaran dan kepedulian akan kebutuhan informasi asuransi bagi masyarakat Indonesiia masih dianggap kurang penting sehingga menuntut industri non perbankan ini untuk lebih giat lagi mengedukasi masyarakat betapa pentingnya kepemilikkan asuransi ini, terutama asuransi syari'ah bagi umat muslim.

Disisi lain, seiring bergantinya periode masehi perkembangan teknologi juga semakin gencar dan pesat. Hadirnya dunia digitalisasi ditengah dominansi masyarakat milenial dan generasi $\mathrm{z}$ ini sangat memfasilitasi dan memotivasi perubahan manajemen pemasaran di pasar ekonomi. pertemuan dan kegiatan transaksi yang dilakukan antara pembeli dan penjual kini lebih praktis,mudah bahkan tidak bisa kita tolak jika seringkali kegiatan pemasaran dan transaksi lebih baik dibanding tanpa adanya dunia digitalisasi.

Dari 196 Juta penduduk yang dijadikan sampel atau 73,7\% dari total sampel penduduk Indonesia 2021 merupakan pengguna aktif jaringan internet (data survey APJII, 2021). Layanan online massage atau chatting menjadi pilihan favorit yang paling sering diakses, sementara media sosial menempatin posisi kedua.

Secara simultan, diartikan jika besar minat penduduk Indonesia akan media sosial yang mampu membuat mereka berkomunikasi lintas provinsi bahkan juga negara. Media sosial sebagai salah satu alat komunikasi sering pula digunakan oleh penggunanya untuk berbagi informasi pengalaman, ulasan, saran, tips bahkan masalah apa pun yang dihadapi seseorang kepada sesama pengguna media sosial. Jika diperhatikan, banyaknya informasi yang tersebar secara bebas itu memudahkan bagian pemasaran untuk membaca dan memahami serta merencanakan segmenting, targeting or positioning produk yang dimiliki. Informasi itu adalah sumber yang bermanfaat, yang mungkin mempengaruhi pengambilan keputusan konsumen (Sema, 2013).

Urgensi menempatkan teknologi digital dalam strategi pemasaran dirasa penting bagi perusahaan asuransi khususnya asuransi syari'ah, mengingat semakin massif dan kompulsif, ditambah lagi pertimbangan keadaan saat ini. Seluruh dunia yang tengah berjuang bersama melawan kondisi pandemi covid-19 yang memaksa yang tidak paham teknologi pun mau tidak mau harus menggunakan teknologi yang ada.

\section{LANDASAN TEORI}

\footnotetext{
${ }^{4}$ https://money.kompas.com/read/2021/07/09/180700926/literasi-asuransi-masih-rendahksk-insurance-dorong-ibu-tunggal-jadi-agen

${ }^{5}$ https://apjii.or.id/downfile/file/BULETINAPJIIEDISI79Januari20211.pdf
} 


\title{
VISA: Journal of Visions and Ideas \\ Vol 1 No 3 (2021) 274-287 E-ISSN 2809-2058 P-ISSN 2809-2643 \\ D0I: 47467/visa.v1i3.809
}

\begin{abstract}
Asuransi Syariah
Berdasarkan UU No. 40 Tahun 2014 mengenai Perasuransian, asuransi syari'ah dimaknai sebagai himpunan perjanjian baik antara perusahaan asuransi syari'ah dengan tertanggung (pemegang polis) maupun antar sesama pemegang polis, bersama menyepakati pengelolaan yang berlandaskan syariat islam akan kontribusi masing-masing peserta/tertanggung untuk saling menolong dan melindungi. Ahli hukum kontemporer, Mustafa Annas al-Zarqa mengatakan jika asuransi syari'ah hukumnya mubah (diperbolehkan). Ia berpandangan jika memang akad asuransi syariah merupakan akad baru sehingga selama tidak ada dalil yang melarangnya, atas dasar kemudahan dalam kegiatan ber-muamalah maka asuransi syari'ah diperbolehkan pelaksanaanya (ijtihad bi al-ra'y dengan metode istișhābī dan ta'līlī, Hasanudin, 2018).
\end{abstract}

Untuk jenis akad yang digunakan dalam asuransi syari'ah, berdasarkan POJK No 69/POJK.05/2016 tentang Penyelenggaraan Usaha Asuransi Syariah, yakni akad tabbaru' (akad hibah dari kumpulan dana tertanggung yang bersama tolongmenolong menanggung kerugian salah satu tertanggung yang mengalami musibah) dan akad tijaroh/wakalh bil ujrah (perusahaan asuransi mendapat upah atas jasa layanan pengelolaan dana tabbaru' dan investasi tertanggung).

\section{Ruang Lingkup Pemasaran}

Pemasaran memiliki kata dasar pasar yang merupakan sarana pertemuan dan tempat dilakukannya transaksi antara penjual dan pembeli. Namun, dari segi istilah diartikan sebagai kegiatan atau tahapan memasarkan, membujuk, menawarkan produk, menyampaikan serta mempertukarkan suatu hal yang memiliki nilai ekonomis. Sedangkan, Kotler dan Keller mengartikan pemasaran sebagai salah satu bentuk seni akan ilmu pemilihan pasar sasaran dengan menciptkan, memelihara, mengembangkan pelanggan melalui penyerahan komunikasi akan nilai kepelangganan yang unggul. American Marketing Association meng-upgrading makna pemasaran yakni Keberfungsian suatu organisasi dalam penciptaan, pengkomunikasian, serta pengantaran nilai ke pelanggan, juga pengelolaan hubungan pelanggan dalam berbagai cara yang diharapkan mampu memberi manfaat bagi organisasi dan kepentingan orang-orang terkait.

Syari'ah memandang pemasaran sebagai segala kegiatan bisnis dalam pengadaan nilai yang dimungkinkan terus bertumbuh dan berkembang guna bisa dirasakan kebermanfaatannya dengan tetap berpegang teguh atas nilai kejujuran, keadilan, keterbukaan dan keikhlasan selama berproses dalam akad muamalah 


\section{VISA: Journal of Visions and Ideas \\ Vol 1 No 3 (2021) 274-287 E-ISSN 2809-2058 P-ISSN 2809-2643 \\ D0I: 47467/visa.v1i3.809}

serta akad dalam transaksi bisnis islami. Mencampurkan atau melakukan pembauran dalam strategi pemasaran dalam hal ini industri asuransi syari'ah diperbolehkan dengan alasan meningkatkan daya jual dan beli serta perolehan laba nantinya, selama tidak ada unsur-unsur yang dilarang dalam islam seperti riba, gharar, maisir baik dalam komposisi produknya maupun cara pemasarannya.

\section{Pemasaran media sosial}

Teknologi interaktif melalui perantaraan computer maupun smartphone yang memberi wadah dalam kreatifitas pengadaan keterangan informasi, usulan ide, dan lainnya dibantu dengan adanya virtual jaringan untuk mengakses perangkat komunikasi daring merupakan pengertian dari media sosial (Kietzmann et al., 2011)6. Pengkategorian layanan media sosial oleh Kaplan dan Haenlein (2010) berupa blog, situs jejaring sosial seperti Facebook, Instagram, Whatsapp; proyek kolaborasi contoh Wikipedia; layanan konten video seperti YouTube; dunia sosial virtual contohnya Second Life; dunia game virtual seperti World of Warcraft, Mobile Legend, Free Fire.

Arigo (2018) mendefenisikan media sosial merujuk pada konsep yang mengikutsertakan berbagai himpunan aplikasi daring, open source, ekspresif yang mampu dikendalikan oleh penggunanya untuk sharing pengalaman bisnis dan sosial (konsep Web 2.0). Lee (2017) berasumsi jika kegiatan perusahaan menggunakan media sosial untuk berkomunikasi, menyebar informasi produk dan perusahaan baik terkait promosi maupun penjualan, serta memperoleh feedback yakni respon target pasarnya merupakan faktor penting dalam kegiatan media sosial perusahaan untuk membandingkan kebutuhan konsumen dan penyesuaian rencana perusahaan agar mampu memenuhi kebutuhan konsumen. Selain itu, Mahnoor Mazhar (2018)

${ }^{6}$ Kietzmann, J.H., Hermkens, K., McCarthy, I.P., Silvestre, B.S. (2017). Social media? Get serious! Understanding the functional building blocks of social media. Elsevier. 


\section{VISA: Journal of Visions and Ideas \\ Vol 1 No 3 (2021) 274-287 E-ISSN 2809-2058 P-ISSN 2809-2643 \\ D0I: 47467/visa.v1i3.809}

dan Khatib (2016) menegaskan jika media sosial juga berperan dalam penentuan merek yang akan membentuk keputusan pembelian produk oleh konsumen.

Pemasaran menggunakan perantara media sosial, sebenarnya menunjukkan kepada tenaga pemasar seberapa berpengaruh teknologi dalam kemudahan antar individu diseluruh dunia saling terhubung secara sosial dengan jejaring sosial yang mereka miliki, dan sejauh mana industri atau perusahaan mampu meraup keuntungan dari penginterprestasian informasi yang tersebar luas di media sosial.

Dengan segala kemudahan pemasaran yang ditawarkan teknologi ini, menjadi diskusi menarik bagi cendikiawan muslim dalam menafsirkan prinsipprinsip syariat pada kegiatan pemasaran Insurtech tersebut. Untuk itu, selama cara marketing insurance memenuhi ketentuan bisnis modern digital namun pada saat yang bersamaan tidak pula membahayakan perlindungan dan promosi indentitas Islam, selagi tidak keluar jalur yang dilarang oleh syariat, maka aktivitas tersebut diperbolehkan (Kasim, 2012).

Islam sebagai sarana mencapai keridhaan-Nya, tidak akan mempersulit, melarang penggiat aktivitas muamalah melakukan usaha untuk memperoleh profit/laba, hanya saja perlu penekanan disini jika selama usaha tersebut ada dalam batas-batasan syariat maka diperbolehkan menghasilkan laba seoptimal dan semaksimal mungkin. Hal itu pula yang menjadikan asuransi syari'ah sejatinnya memiliki tujuan yang lebih luas daripada sekadar mencari keuntungan material.

Untuk mengatahui dampak apa saja yang harus dihadapi akibat pemasaran melalui media sosial, maka perlu membaca dan memahami penelitian-penelitian terbaru maupun terdahulu terkait hal tersebut. Seperti hasil penelitian oleh Abzari et al. (2014) menyimpulkan bahwasannya iklan tradisional dan media sosial memiliki dampak signifikan terhadap brand attitude. Tetapi, iklan tradisional berpengaruh lebih kecil dibanding dengan pengaruh iklan melalui media sosial. Bukan hanya berefek pada sikap dan daya beli calon konsumen, Morwitz (2014 dalam Lim et al., 2017) menginterpretasikan minat/daya beli juga bisa dimanfaatkan untuk memperkirakan prediksi daya jual dan penentuan pangsa pasar selanjutnya.

Hilal (2018) mengungkapkan bahwasannya pemasaran media sosial bersumbangsih dalam terbentuknya ketulusan (equitableness) serta prestise suatu merek/brand diantara konsumen dan calon konsumen. Sejalan dengan hasil penelitian Hilal, Values, relationship, and brand equity juga menjadi perantara yang berpengaruh dalam pembentukkan keputusan aktivitas pembelian produk (Kosarizade dan Hamdi,2015). Melengkapi penelitian Hilal dan Kosarizade bersama 


\section{VISA: Journal of Visions and Ideas \\ Vol 1 No 3 (2021) 274-287 E-ISSN 2809-2058 P-ISSN 2809-2643 \\ D0I: 47467/visa.v1i3.809}

Hamdi, Laksamana (2018) menyimpulkan jika media sosial dlaam pemasaran berdampak pada daya minat membeli dan keloyalan terhadap merek.

\section{Teori Komunikasi Pemasaran}

Sentral marketing berfokus pada pemasaran dan perilaku konsumen atas dasar pertukaran (uang dengan produk yang dibutuhkan atau diinginkan) dengan tujuan akhir yakni perolehan kepuasan (Richard J. Varey, 2002).7

4P menjadi acuan dasar sebagai perencanaan sebelum melakukan aktivitas pemasaran menurut (Zaharuddin, 2006: 81) yaitu :

1. Product, berbentuk barang maupun jasa apa yang akan diproduksi juga ditawarkan mempertimbangkan kebutuhan, keinginan dan kepuasan pasar sasaran. pasar sasaran.

2. Price, nominal harga (uang) yang harus ditukarkan sebagai bukti kepemilikan produk barang atau jasa yang dimau.

3. Place, berbagai kegiatan yang dilakukan perusahaan untuk membuat produknya mudah diperoleh dan tersedia untuk konsumen sasaran.

4. Promotion, mempublikasikan produk baik melalui iklan tradisional atau melalui media sosial, penjualan individu, diskon/promo sebagai bentuk bujukan dan pengenalan produk agar calon pelanggan membelinya.

\section{Pemasaran Asuransi Syari'ah Pada Media Sosial Di Era Pandemi}

Media sosial di era pandemi Covid-19 kini menjelma menjadi seperti suatu hal yang menyebabkan ketergantungan pemakainya untuk beraktivitas sehari-hari. Salah satunya kegiatan pemasaran asuransi syari'ah yang menggunakan media sosial komunikasi pesan tertulis atau lisan aplikasi zoom, google meet or whatsapp. Pada umumnya, isi pesan grup whatsapp atau sejenisnya pada suatu perusahaan bisnis di era pandemi ini akan menampilkan bahasan terkait :

1. Arahan penjualan daring (produk, harga, promosi), strategi teknikal merekurt nasabah dan agen secara daring, webinar ke instansi atau acara terkait bahasan asuransi melalui zoom, google meet, instagram live, atau personal direct massage media sosial.

2. Sistem operasional penyebaran masif akan grafik,data maupun gambar secara keseluruhan bukan lagi hanya data-data tertentu saja di grup whatsapp, agar setiap pimpinan bidang mampu memahami tugas dan tanggung jawab apa yang harus tanggung jawabi ke depannya. Serta

\footnotetext{
${ }^{7}$ https://pakarkomunikasi.com/teori-komunikasi pemasaran
} 


\section{VISA: Journal of Visions and Ideas \\ Vol 1 No 3 (2021) 274-287 E-ISSN 2809-2058 P-ISSN 2809-2643 D0I: 47467/visa.v1i3.809}

pengetatan aktivitas pemantauan pimpinan bidang dan agen untuk mendongkrak kembali produksi yang dirasa turun akibat pandemi.

Bahasan pemeliharaan pemasaran yang dilakukan agen serta cara mempertahankan juga meningkatkan jumlah dan keloyalan nasabah asuransi menjadi topik utama dan penting bagi tenaga pemasar virtual dimasa pandemi ini. Pemasaran diasumsikan sebagai suatu tindakan pelayanan dan pemasaran yang kreatif dan dinamis, dimana tenaga pemasar diharapkan mempunyai perspektif luas dan dinamis dalam menciptakan peluan sehingga mampu berinteraksi dan menggaet banyak orang/nasabah baru (Godin, 2018).

\section{Komunikasi Virtual}

Berbicara mengenai komunitas virtual tentunya otomatis membahas komunikasi virtual. Mengutip dari Prabowo RC ( 2020 ) :

Komunikasi virtual terdiri atas dua unsur antaralain komunkasi yaitu penyampaian pesan informasi dengan tujuan mendapatkan respon balik atas informasi yang telah disampaikan sebagai bentuk pengyakinan jika informasi yang ingin disampaikan sesuai dengan maksud informan pertama. Serta virtual yang berarti dalam proses komunikasi tesebut memanfaatkan media video call, video conference dan sebagainya yang tentunya akan lebih efektif dan efisien dalam penghematan dana perusahaan, dibandingkan harus melalui komunikasi personal selling. Keunggulan lainnya, selain efektif dan efisien jangkauan pemasaran ini juga mampu melintasi kota, provinsi bahkan negara. Tatap muka tidak lagi perlu dilakukan secara luring, jika karena suatu keadaan tertentu yang memaksa nasabah atau calon nasabah tidak bisa bertemu dengan agen secara luring, tatap muka tetap bisa dilakukan melalui panggilan video. Sehingga, tanya jawab, diskusi tetap bisa berjalan dengan adanya bantuan digitalisasi komunikasi ini.

\section{METODOLOGI PENELITIAN}

Pendekatan deskriptif kualitatif merupakan metode penelitian yang digunakan oleh peneliti. Dari metode penelitian tersebut akan dihasilkan data berbentuk deskriptif (gambaran) yang terdiri dari sikap seseorang yang menjadi objek penelitian, dalam hal ini nasabah asuransi syariah dengan digitalisasi, teknologi dan media sosial merupak subjek penelitian. Serta kata-kata tertulis sebagai hasil dari penelitian kualitatif yang berkaitann dengan persepsi/perspektif, argumen dan gagasan terkait judul penelitian. Sumber data yang diperoleh peneliti merupakan data primer yang didapatkan dari kajian-kajian penelitian terdahulu dalam karya tulis ilmiah serta teori-teori yang membahas potensi perencanaan pemasaran syari'ah melalui media sosial. Demikian pula untuk teknik pengumpulan data, peneliti menerapkan proses observasi media sosial beberapa perusahaan asuransi syari'ah yang telah melakukan digitalisasi pemasaran terhadap produknya. 


\section{VISA: Journal of Visions and Ideas \\ Vol 1 No 3 (2021) 274-287 E-ISSN 2809-2058 P-ISSN 2809-2643 \\ D0I: 47467/visa.v1i3.809}

\section{HASIL DAN PEMBAHASAN}

Sikap dan tindakan nasabah atau calon nasabah yang tergolong konsumtif serta cenderung menyukai cara instant atau tidak mau ribet (mageran), menjadi suatu peluang bagi pelaku industri asuransi syari'ah dalam mendobrak peningkatan penjualan melalui digitalisasi pemasaran. Namun, perlu ditanamkan kembali dalam diri setiap tenaga pemasar agar tetap menjalankan strategi pemasaran tanpa ada tindakan saling menjatuhkan antar pesaing. Untuk itu, merupakan suatu tantangan bagi tenaga pemasar untuk bisa mempertahankan pola pemasaran yang tepat dan cermat dengan tanpa melepaskan prinsip dan kode etik dalam layanan yang optimal.

Dilapangan, sering kita temui pola pemasaran yang diaplikasikan oleh para pelaku bisnis umumnya berorientasi pada pencapaian profit (material) semata, mereka hanya memikirkan bagaimana caranya pemasaran mampu memotivasi peningkatan penjualan, mereka sering pula lupa jika tujuan sejati dari diadakannya aktivitas pemasaran sebenarnya sebagai wujud upaya permberdayaan dan pengedukasian bagi target pemasaran.

Bahkan, jika dilihat secara saksama kembali bahwasannya perkembangan teknologi dan digitalisasi yang merambah ke segala aspek kehidupan ini, baik itu bidang pendidikan maupun ekonomi, paradigma strategi industri non syari'ah sudah mulai hijrah mengarah ke spiritual marketing atau pemasaran syariah, dengan bantuan teknologi dan media sosial.

Sebelum dunia dihadapkan dengan kondisi pandemi covid-19, segala proses pemasaran produk asuransi syari'ah dilakukan secara luring/langsung tatap muka bersama calon nasabah baik itu penyebaran informasi door to door, dari mulut ke mulut ataupun melalui iklan tradisional (media cetak), serta ada beberapa perusahaan asuransi syari'ah pula yang memulai startegi pemasaran melalui media sosial. Namun kini, adanya pandemi terutama diawal masa pandemi membuat segala kegiatan harus dilakuka secara daring. Konsep ini bukan merupakan suatu kesalahan, namun memang semakin berkembangnya zaman maka akan ditemukan pula segala kemudahan yang lebih baik dalam meringankan kegiatan ekonomi khususnya yang lebih baik dari tahun-tahun sebelumnya. Strategi dimasa lalu dengan perkembangan teknologi yang belum sepesat sekarang memang cukup banyak menghabiskan dana dan waktu yang ada, kurang efektif dan efisien dalam menggapai seluruh segmen dan target yang ditentukan jika dinilai dengan kehidupan masa kini.

Sekali lagi, kini, dunia telah berkembang dan bertumbuh banyak perubahan dalam segala aspek, begitupun dalam segala aspek ekonomi dan atau hal-hal lainnya. Begitupula dalam hal pemasaran, manajemen pemasaran saat ini dituntut kesediaannya merancang konsep pemasaran yang berbaur dengan teknologi. 


\section{VISA: Journal of Visions and Ideas \\ Vol 1 No 3 (2021) 274-287 E-ISSN 2809-2058 P-ISSN 2809-2643 DOI: 47467/visa.v1i3.809}

Insurance Technology (Insurtech) yakni kombinasi gabungan antara asuransi dan teknologi bersama komponen financial lainnya (financial technology) yang turut serta melengkapi strategi ini. Research Daily Social, "Insurance Technology Research 2019" menyimpulkan sekitar 69,4\% responden familiar dengan istilah insurtech dan 83,9\% dari responden pernah membeli asuransi melalui insurtech. Mayoritas responden 41,46\% responden mengetahui insurtech melalui media sosial. Meskipun strategi pemasaran asuransi bersama teknologi masih menyumbangkan nominal angka kecil/rendah dari total kontribusi asuransi, namun bukan tidak mungkin dimasa mendatang berpotensi menyumbangkan angka kontribusi yang tinggi.

Dengan memperhatikan hasil data tersebut, memang menampilkan gambaran peluang besar bagi kemajuan pangsa pasar industri asuransi syari'ah. Lagi-lagi sangat disayangkan, faktanya masyarakat muslim Indonesia masih lebih percaya sehingga lebih memilih menggunakan atau membeli produk asuransi non syari'ah. Masih sangat terbatasnya penelitian-penelitian startegi pemasaran industri asuransi syari'ah pada media sosial, turut bersumbangsih dalam menunjukkan jika pemasaran media sosial berpengaruh dalam perilaku dan keinginan membeli suatu produk syari'ah seseorang.

Asuransi syari'ah tentu dikenal sebagai sebuah brand yang dalam segala aspek dan komposisi kegiatannya ditandai dengan adanya perbedaan apakah suatu asuransi tesebut pengelolaannya telah sesuai dengan standard dengan prinsip syari'ah atau belum, atau masih bercampur dengan asuransi konvensional. Sebagai konsumen muslim yang benar-benar menerapkan prinsip dan etika konsumsi seorang muslim sudah pasti akan sangat memperhatikan status kehalalan suatu produk barang maupun jasa yang akan ia konsumsi (Aji, 2019). Untuk itu segala produk keuangan syari'ah baik perbankan maupun non perbankan seperti asuransi syari'ah harus dipastikan telah ada diposisi dalam batasan aturan dan ketentuan syari'ah, yang jauh dari segala wujud fisik maupun empirik yang menunjukkan kearah penipuan, riba, ketidakjelasan resiko yang dipertangunggkan, klaim asuransi yang dilebihkan atau disembunyikan jumlah uang pertanggungan yang sebenarnya (gharar, maisyir). Setelah dipastikan seluruh produk mampu mematuhi ketentuan hukum syariat maka hal ini akan berdampak sebanding dengan mampunya produk syari'ah tersebut menarik minat daya beli konsumen muslim.

Selain status kedudukan produk yang diajukan, perusahaan juga perlu mencermati kembali bagaimana produk tersebut diperdagangkan pada pasaran. Contohnya dengan tidak melakukan promosi yang di dalamnya terkandung unsur penipuan, menjatuhkan atau mengatakan produk perusahaan A buruk dan begitupun produk perusahaan BCDE, melakukan advertensi produk yang sebenarnya produk tersebut tidak memiliki keunggulan seperti yang ada dipromosi (bai' najasy). Untuk itulah disini pentingnya keberadaan beberapa variable pemasaran media sosial yang memiliki kepatuhan terhadap aturan syari'ah (sharia compliant in social media marketing) guna memaparkan penjelasan apa saja hal-hal yang mempu mempengaruhi minat konsumen muslim terhadap asuransi syari'ah. 


\section{VISA: Journal of Visions and Ideas \\ Vol 1 No 3 (2021) 274-287 E-ISSN 2809-2058 P-ISSN 2809-2643 D0I: 47467/visa.v1i3.809}

Masyarakat milenial dan generasi z saat ini mendayagunakan pemanfaatan informasi yang ada di media sosial sebagai wadah perantara komunikasi pemasaran antara ia dengan perusahaan yang bersangkutan serta memanfaatkan kemudahan lampiran informasi yang tersebar di dunia digitalisasi ini untuk kemudahan pencarian informasi berkomunikasi serta proses transaksi jual beli. Pemasaran melalui media sosial merupakan total keseluruhan proses kegiatan dalam pemanfaatan digitalisasi dan teknologi untuk bisa mengajak calon pelanggan menyadari nilai dari suatu produk yang ditawarkan serta pelayanan apa saja yang akan ia dapatkan sehingga mampu memenuhi semua kebutuhannya terkait suatu hal (Kosarizade dan Hamdi, 2015).

Tantangan bagi industri asuransi syari'ah yang ada di Indonesia, salah satu diantaranya tantangan aspek geografis wilayah Indonesia yang merupakan negara dengan ribuan pulau, jutaan penduduk dengan ribuan suku yang pastinya juga akan menjadi tantangan tersendiri bagi tenaga pemasar untuk bisa mengedukasi agar target pasarnya memahami setidaknya sadar bahwa asuransi itu merupakan suatu kebutuhan. Maka dari itu, upaya literasi dan akses terhadap asuransi ini bisa cepat diselesaikan jika calon nasabah dan tenaga pemasar asuransi mampu menggunakan media sosial dan teknologi yang ada secara sinergis berkelanjutan. Peningkatan teknologi, membuka pintu penyaluran dan komunikasi asuransi melalui jalur digital selain melalui cara tradisional/konvensional. Menurut data AAJI per bulan September 2019, penjualan premi melalui jalur digital baru mencapai 0,01\% dari total penjualan premi baru Rp54,57 triliun.

Asuransi dewasa ini menjadi bisnis non perbankan yang semakin diminati oleh masyarakat setelah bisnis perbankan. Menurut data dari OJK, terdapat 19 Unit Usaha Syariah dari Perusahaan Asuransi Konvensional yang menjual khusus produk asuransi berbasis syariah. Arah ini dilakukan perusahaan asuransi melihat peningkatan minat dan ketertarikan masyarakat terhadap produk berbasis syariah. Di samping itu, perusahaan juga melihat penduduk Indonesia yang mayoritas beragama Islam, sehingga peluang penjualan produk berbasis syariah semakin terbuka lebar.

Agen asuransi adalah ujung tombak perusahaan asuransi dalam memasarkan produk- produk perusahaan. Acuan dasar penilaian keberhasilan seorang agen asuransi dapat dilihat dari seberapa banyak ia mampu mendapatkan nasabah dalam jangka waktu tertentu, yang dalam hal ini dapat pula kita artikan, berapa banyak nasabah yang telah teredukasi dengan baik sehingga ia mampu menyadari pentingnya kepemilikan asuransi karena memang hal tersebut merupaka salah satu diantara kebutuhannya. Setiap perusahaan asuransi mempunyai peraturan dan ketentuan yang berbeda untuk penjualan produk asuransi, yang 


\section{VISA: Journal of Visions and Ideas \\ Vol 1 No 3 (2021) 274-287 E-ISSN 2809-2058 P-ISSN 2809-2643 \\ D0I: 47467/visa.v1i3.809}

merupakan juga sebagai bentuk diferensiasi perusahaannya dengan perusahaan asuransi lainnya.

Bagi beberapa agen dari perusahaan asuransi konvensional, ada juga diantara mereka yang melakukan penawaran produk asuransi konvensional dan juga asuransi syari'ah. Memang belum ada undang-undang yang mengatur penjualan kedua produk ini. Namun, islam tidak membernarkan kegiatan penawaran tersebut. Bahwa produk syari'ah tidak bisa diajukan bersamaan dengan yang non syariah yang telah jelas ada riba dan unsur lainnya yang dilarang islam diproduk tersebut. Jika tenaga pemasar tersebut mengajukannya secara terpisah, maka diperbolehkan. Sayangnya, kebanyakan agen mencampuradukkan kedua penjualan produk tersebut, tentu saja hal ini diharamkan dalam islam.

\section{KESIMPULAN}

Berada dikehidupan pada masa era milenial dan generasi $\mathrm{Z}$ yang dalam beraktivitas dalam kegiatan sehar-hari menginginkan segalanya dipermudah melalui teknologi, bisa diperoleh dengan cara instant, serta bagi kaum mageran mengharapkan kemudahan aktivitas tanpa perlu melakukan pergerakan yang menguras banyak tenaga. Ditambah lagi keadaan dunia saat ini masih terus berjuang dan bertahan selama masa pandemic covid-19, tentu membuat segala aspek kehidupan diharuskan dilakukan melalui rumah masing-masing tiap individu. Sejalan dengan semua kendala dan keinginan di atas, perkembangan teknologi kini juga semakin gencar dilakukan, sehingga mampu menjawab atau memberi solusi atas permasalah yang dimaksudkan. Jika sebelumnya penyebarluasan informasi khususnya dalam manajemen pemasaran membutuhkan perlengkapan atau media yang begitu rumit dan yang juga belum tentu menggapai seluruh target yang dimaksud, kini semuanya telah berubah. Semuanya relatif lebih efektif dan efisien ketika dibantu oleh perangkat-perangkat teknologi.

Batasan informasi yang sebelumnya dirasa cukup membebani diri, kini adanya media sosial membuat tiap individu mampu menggali sendiri segala informasi yang ia inginkan lebih dalam. Atau bagi beberapa orang, kemudahan memperoleh informasi ini membuatnya menjadi lebih kritis akan perkembangan yang terjadi saat ini. Menilik fenomena ini, ternyata komunikasi virtual turut berkontribusi dalam pengakselerasian pertukaran pesan secara global. Penerapan strategi pemasaran asuransi syari'ah memanfaatkan penggunaan media sosial baik itu facebook, instagram, whatsapp ataupun konten youtube/tik tok, bukan hanya mampu membuat tampilan menarik bagi daya jual suatu produk, namun juga secara tidak langsung membujuk alam bawah sadar pengguna media sosial yang menjadi target pemasaran membuat keputusan untuk membeli produk tersebut.

\section{DAFTAR PUSTAKA}




\section{VISA: Journal of Visions and Ideas \\ Vol 1 No 3 (2021) 274-287 E-ISSN 2809-2058 P-ISSN 2809-2643 D0I: 47467/visa.v1i3.809}

Adiputra, Eka. (2015). "Perilaku pembelian tidak terencana (Impulse buying) dipusat Perbelanjaan Modern di Surabaya". Jurnal An-Nisbah. Vol. 01, No. 02. hlm. 150-180.

Gunawan, Miming Saputra. (2021). "Komunikasi Kelompok Virtual Pada Grup Whatsapp Victory West Leader Pemasaran Asuransi Di Era Pandemi Covid19". Jurnal Ekonomi dan Bisnis, P - ISSN : 2503-4413, E - ISSN : 2654-5837, Hal 198 - 2, Vol. 8 No. 2.

Husin, M, Rahman, A. (2014). Do Muslims intend to participate in Islamic insurance? Analysis from theory of planned behaviour. Emerald Insight.

Iqbal, Reza Muhammad, Neni Sri Imaniati, Neneng Nurhasanah Tinjauan. (2017). "Hukum Islam Terhadap Pencampuran dalam Pemasaran Produk Asuransi Konvensional dan Asuransi Syariah oleh Perusahaan Asuransi Konvensional, Prosiding Keuangan dan Perbankan Syariah". ISSN: 2460-2159, Volume 3, No.2.

Kietzmann, J.H., Hermkens, K., McCarthy, I.P., Silvestre, B.S. (2017). Social media? Get serious! Understanding the functional building blocks of social media. Elsevier.

Kurniawati, Dewi. (2015). "Strategi Pemasaran Melalui Media Sosial Dan Minat Beli Mahasiswa”. Jurnal Simbolika, Vol. 01, No. 02, hlm. 193-200.

Kotler, P., \& Keller K.L. (2012). Marketing Management. New Jersey: Prentice Hall.

Muali, Chusnul, Khoirun Nisa. (2019). "Pemasaran Syariah Berbantuan Media Sosial: Kontestasi Strategis Peningkatan Daya Jual”. An-Nisbah : Jurnal Ekonomi Syariah, Vol. 05 No. 02.

Putri, Dini Amalia. "Pengaruh Pemasaran Media Sosial Terhadap Purchase Intention Asuransi Syariah di Indonesia". Aghniya Jurnal Ekonomi Islam, ISSN: 26565633, Vol.2 Nomor 2 Juni 2020.

https://apjii.or.id/downfile/file/BULETINAPJIIEDISI79Januari20211.pdf

https://databoks.katadata.co.id/datapublish/2021/09/30/sebanyak-8688-

penduduk

indonesiaberagamaislam\#: :text=Persentase \%20Pemeluk\%20Agama\%2FKeperca yaan\%20di\%20Indonesia\%20(Juni\%202021)\&text=Berdasarkan\%20data\%20Dire ktorat $\% 20$ Jenderal $\% 20$ Kependudukan,86\%2C88\%25)\%20beragama\%20Islam.

https://dspace.uii.ac.id/bitstream/handle/123456789/14488/06\%20BAB\%20II.pd f?sequence6

https://money.kompas.com/read/2021/09/21/130524326/industri-asuransisyariah-lanjutkan-pertumbuhan-positif-pada-kuartal-ii-2021

https://money.kompas.com/read/2021/07/09/180700926/literasi-asuransimasih-rendah-ksk-insurance-dorong-ibu-tunggal-jadi-agen

https://pakarkomunikasi.com/teori-komunikasi pemasaran 


\section{VISA: Journal of Visions and Ideas}

Vol 1 No 3 (2021) 274-287 E-ISSN 2809-2058 P-ISSN 2809-2643

D0I: 47467/visa.v1i3.809

http://repository.unj.ac.id/10331/3/BAB\%202.pdf 